\title{
Estimating the Impact on Water Quality under Alternate Land Use Scenarios: A Watershed Level BASINS-SWAT Modeling in West Georgia, United States
}

\author{
Gandhi Bhattarai ${ }^{1}$, Diane Hite ${ }^{2}$ and Upton Hatch ${ }^{3}$ \\ ${ }^{1}$ HealthCare Innovation and Information, Ingenix \\ ${ }^{2}$ Agricultural Economics and Rural Sociology, Auburn University \\ ${ }^{3}$ Agricultural and Resource Economics, North Carolina State University
}

USA

\section{Introduction}

Non-point source pollution (NPP) is caused by the movement of water over and through the ground, generally after each rainfall. The runoff picks up and carries away natural and manmade pollutants, eventually depositing them in water bodies like lakes, rivers and coastal waters. Thus the pollutants left on the surface from various sources accumulate in receiving water bodies. For example, crop cultivation requires more use of chemicals and nutrients than natural vegetative cover like forest and grasslands. Tillage operations affect the soil structure and the level of chemicals in the soil. Such activities make the nutrient rich topsoil fragile and cause it to lose more chemicals and soil particles during rainfall. Lands in residential and development uses, such as lawns and gardens are managed more intensively, which encourages the generation of even more pollutants. On the other hand, urban areas have higher percentages of impervious to porous surfaces that result in low percolation and higher runoff. During precipitation, the runoff carries more nutrients and sediments from agricultural and residential lands resulting in higher chemical level and turbidity in the water. Thus increasing urbanization coupled with increasing use of nutrients and chemicals in agricultural lands create significant challenges to maintain water quality.

Recent water quality studies have focused on developing and successfully applying various biophysical simulation methods to model levels of NPP and to identify critical locations from which these pollutants originate (Bhuyan et al., 2001; Mankin et al. 1999; Marzen et al., 2000). These models collect and use various geospatial data, facilitating the spatial analysis of sources and effects of point and non-point pollutants with reference to their origin and geographical locations. The findings of such models help the environmental policy planners to understand both the short-term and long-term effects of changes from alternative land management scenarios and simulate how the pollution can be reduced effectively through the institutionalization of best management practices. This study uses the BASINS-SWAT modeling framework, one of the latest biophysical modeling tools to estimate the effects of land use change in the quality of water. Simulations are done to estimate the level of 
nitrogen, phosphorus and sediment loads using two time period land use maps. This study demonstrates the use of geospatial technologies to gather and organize reliable and current data for inputs into the BASINS-SWAT model runs.

\section{The modeling approach}

Better Assessment Science Integrating Point and Non-point Sources (BASINS) is a multipurpose environmental analysis system developed by U.S. Environmental Protection Agency's Office of Water. It is used in performing watershed-and water-quality-based studies and can support analysis at a variety of scales using different tools. BASINS can support implementation of TMDLs by state agencies using watershed-based point and nonpoint source analysis for a variety of pollutants including the alternative land management practices. It comprises a suite of interrelated components for performing the various aspects of environmental analysis including data extraction, assessment, watershed delineation, classifying digital elevation models (DEM), land use, soils and water quality observations, and watershed characterization reports (United States Environmental Projection Agency [USEPA], 2001).

Soil and Water Assessment Tool (SWAT) is a river basin or watershed scale model developed by the USDA Agricultural Research Service's Grassland, Soil and Water Research Laboratory which has become an integral component of BASINS. It was designed to assist resource managers in the long-term assessment of sediment and chemical yields in large watersheds and river basins. The model can predict the average impact of land use and management practices on water, sediment, and agricultural chemical yields in large, complex watersheds with varying soils, land uses, and management conditions over long periods of time (DiLuzio et al., 2002; Neitsch et al., 2002). In comparative studies using hydrologic and non-point source pollution models, SWAT has been shown to be among the most promising for simulating long-run NPP in agricultural watersheds (Borah and Bera, 2003).

BASINS-SWAT uses an ArcGIS Geographic Information System interface to derive the model input parameters and simulation. Hydrological modeling relies on elevation data in which watershed and subwatersheds are delineated based on the terrain and flow direction of raindrops. The watershed drains at the lowest point of the catchment area and contains several sequential subwatersheds with directional flow (raindrop flow) to the main channel based on the topography of land and user supplied intermediate outlet points. Subwatersheds are grouped based on climate, hydrologic response units (HRUs), ponds, ground water, and main channels (Borah \& Bera, 2003). Each subwatershed is virtually divided into several hydrological response units (HRUs) which are uniquely lumped areas within the subwatershed based on weighted land cover, soil type, and management combinations at a certain threshold level, generally 10\% in practice (Saleh et al., 2000). SWAT model simulation requires weather parameter inputs (precipitation, wind, temperature) and management parameter inputs (irrigation, tillage, chemical and fertilizer application). These input variables are converted to standard SWAT input files within the model. The model then simulates the runoff levels of nutrients, chemicals and sediment loadings, as well as crop yields, under a particular combination of land management scenarios. SWAT output can be traced across the watersheds both for short and long period of times. 


\section{Study area}

This study is based on the Mulberry Creek Watershed a 10-digit coded Hydrological Unit (HUC \#0313000212) in Harris County, Georgia, nested within the Middle Chattahoochee watershed (HUC\# 03130002). The area is situated to the north of Columbus, GA and covers approximately $50 \%$ of the county surface area. The map of study area is given in Figure 1.

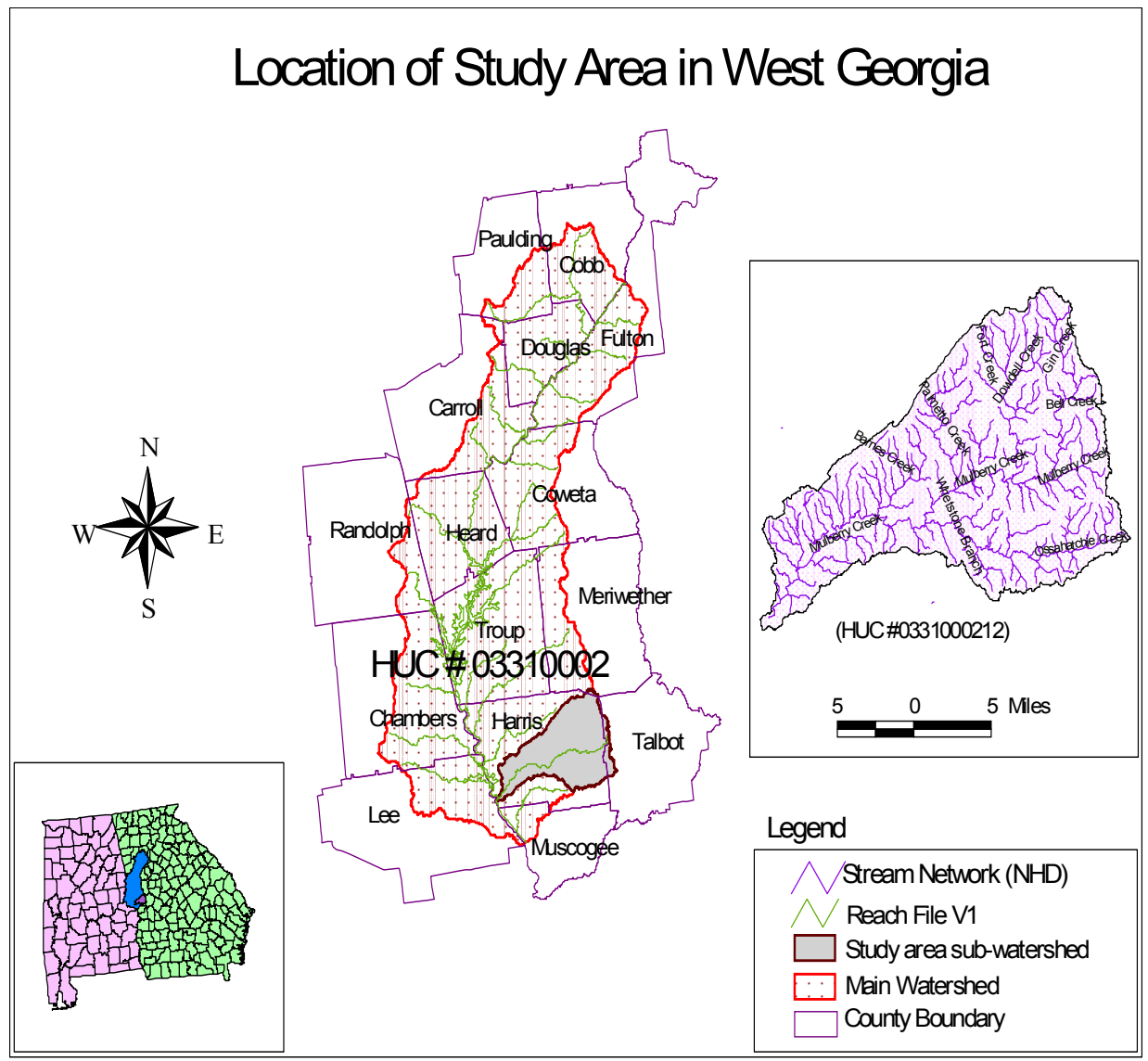

Fig. 1. Map of Study Area

Harris County has experienced a tremendous market influence due to the expansion of the Columbus Metropolitan Area in the last two decades. Limited by the Chattahoochee River on the west and by a military base on the south, the suburban area is expanding mostly to the north and northeast. Harris County experienced a $33.2 \%$ increase in total population between 1990 and 2000 census years (United States Census Bureau, 1990, 2000). In the same time, the population in Troup and Muscogee counties increased only by $5.8 \%$ and $3.9 \%$ along the north and south boarder of the county respectively. On the other hand, Talbot County, which is mostly rural and lies to the east of Harris County did not see any increase 
in its population. As the demographic structure and other socioeconomic conditions in the area changed between 1990 and 2000 census years, land use distribution has also changed. This provided a very good experiment site to estimate the water quality impact of land use change. Figure 2 compares the land use scenarios within the Mulberry Creek watershed using the National Land Cover Datasets 1992 and 2001 (NLCD-1992 and NLCD-2001).

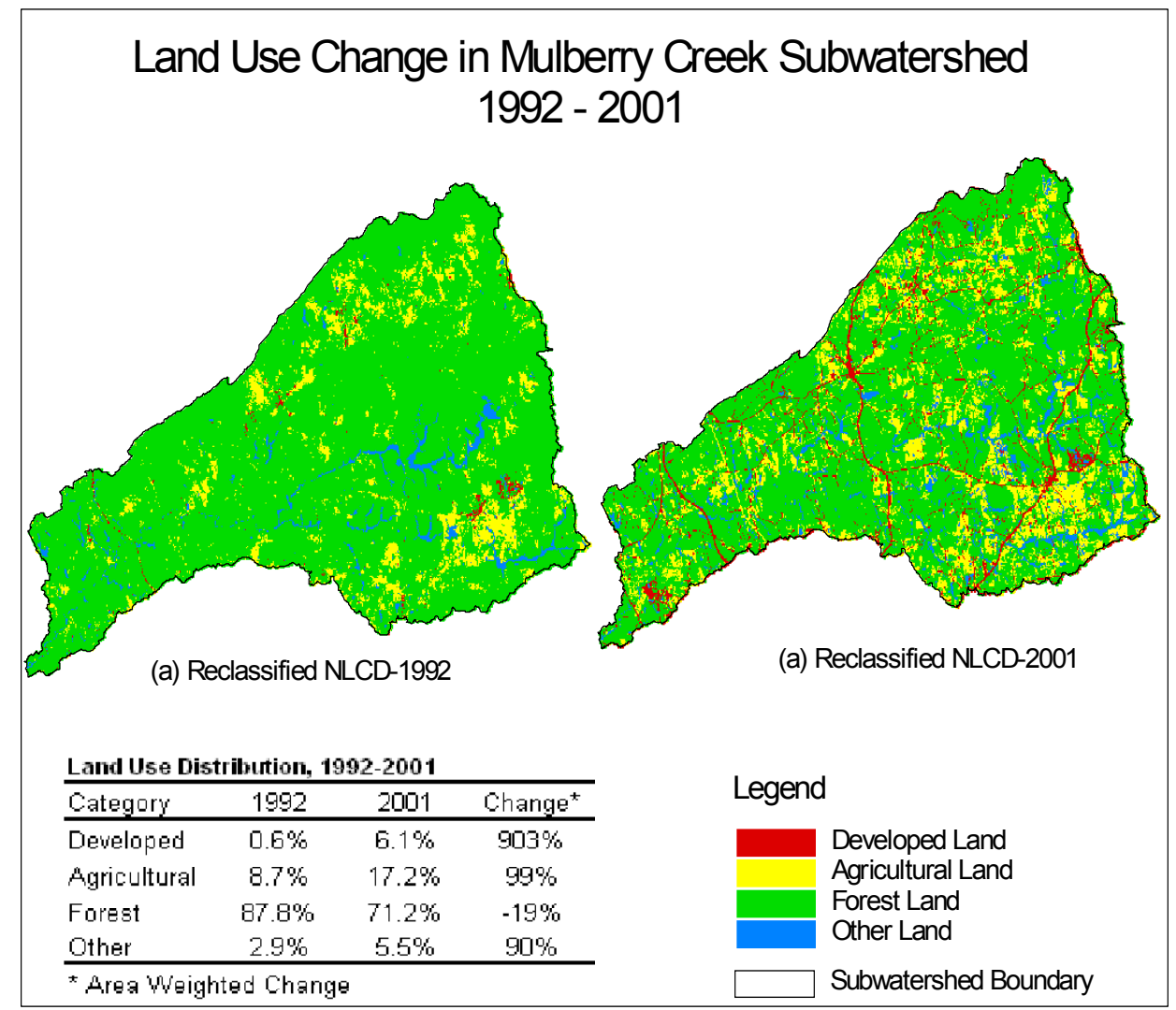

Fig. 2. Land use distribution in Mulberry Creek sub-watershed

Delineated watershed covered 58,323 hectares in size, roughly half of the total area in Harris County, GA. There has been significant change in the distribution of land use in the Mulberry Creek sub-watershed between 1992 and 2001. For comparison, land use grids were broadly reclassified into developed, agricultural, forest and other lands for both years. In NLCD-2001, forest land covered 71.2\% of total area, down from 87.8\% in NLCD-1992. Share of agricultural land increased to $17.2 \%$ in NLCD-2001, about two times bigger than in NLCD-1992.Developed land share increased by nine-fold in NLCD-2001. Broadly reclassified land use distribution is given in Figure 2.

The change in the land use pattern in the area is expected to bring changes in water quality through different levels of point and non-point source pollution. According to the EPA's list 
of impaired water, 13 total maximum daily loads (TMDLs) had been approved in the Middle Chattahoochee Watershed between 1996 and 2004 (EPA, Surf Your Watershed).

\section{Methodology}

\subsection{Data collection and processing}

The study uses secondary data obtained from various sources. The sources and processing of the individual data components is described below.

Core BASINS data: Once the BASINS project was opened, basic datasets were extracted from various sources using the data download extension within the BASINS program. These files included various boundary shape files at watershed, county and state levels, soil and land use grids, locations of water quality stations, bacteria stations, USGS gage stations, permit compliance systems and National Hydrography Data (NHD). The BASINS view was projected to Albers Equal-Area Conic projection system. All subsequent data were projected in the same system using grid projector tool in BASINS.

NEM data: The 1:24,000 scale 30x30m resolution national elevation model (NEM) data for the entire area was downloaded from Seamless Data Distribution System of USGS Web Server. The dataset was converted to grid files using ArcView Spatial Analysis tool.

Land use data: Two sets of spatial land use data were obtained from Seamless Data Distribution System of USGS Web Server. The first land use map was the National Land Cover Database 1992 (NLCD-1992), which was prepared based on satellite images taken circa 1990. The second land use map was the National Land Cover Database 2001 (NLCD2001). This map was prepared from satellite images taken circa 2000. Both of the land cover maps had 30x30m resolution at the scale of 1:24,000 (USGS MRLC metadata information). Land use grids were re-projected to match with the NEM grids projection.

Climate Data: SWAT model uses climate information including precipitation, temperature, wind speed, solar radiation and relative humidity data. However, when no such data are available, the model has capability to simulate data based on historical weather observations from the nearest of more than 800 climate stations (SWAT Users' Manual). Observed daily precipitation and minimum/maximum temperature data were obtained from the National Climate Data Center (NCDC) database for ten nearby climate stations between January 1945 and December 2004. Raw precipitation and temperature data were converted into SWAT readable individual database files for each station.

\subsection{Watershed modeling process}

Once all data were collected and the geospatial data layers were re-projected and matched to a single view, the BASINS process started with preprocessing of DEM to remove any sinks and holes in the DEM coverage. A masking grid covering the anticipated area of watershed was used as focus area and a Reach File used as a burn-in option to enhance the watershed delineation process. After the preprocessing of DEM, digital stream networks were created with a 100-hectare headwater threshold area, which defines the minimum area required to begin a stream flowing out of the area in any part of the watershed (Figure 3). As a standard, the typical value is 5000 cells (450 hectares) when using National Elevation Dataset. Although any values can be used, threshold under 1000 cells or 90 hectares becomes questionable in the areas of flat terrain (Maidment, 2002).

The lowest outlet point at the stream network was selected as the drainage outlet to define the watershed boundary. Spurious nodes were removed and very long river segments were divided into outlet nodes during the calculation of sub-basin parameters to ensure a 
uniform size distribution of sub-basins. Sub-basin parameters were calculated within the model that makes the use of DEM and stream network (Figure 4-5).

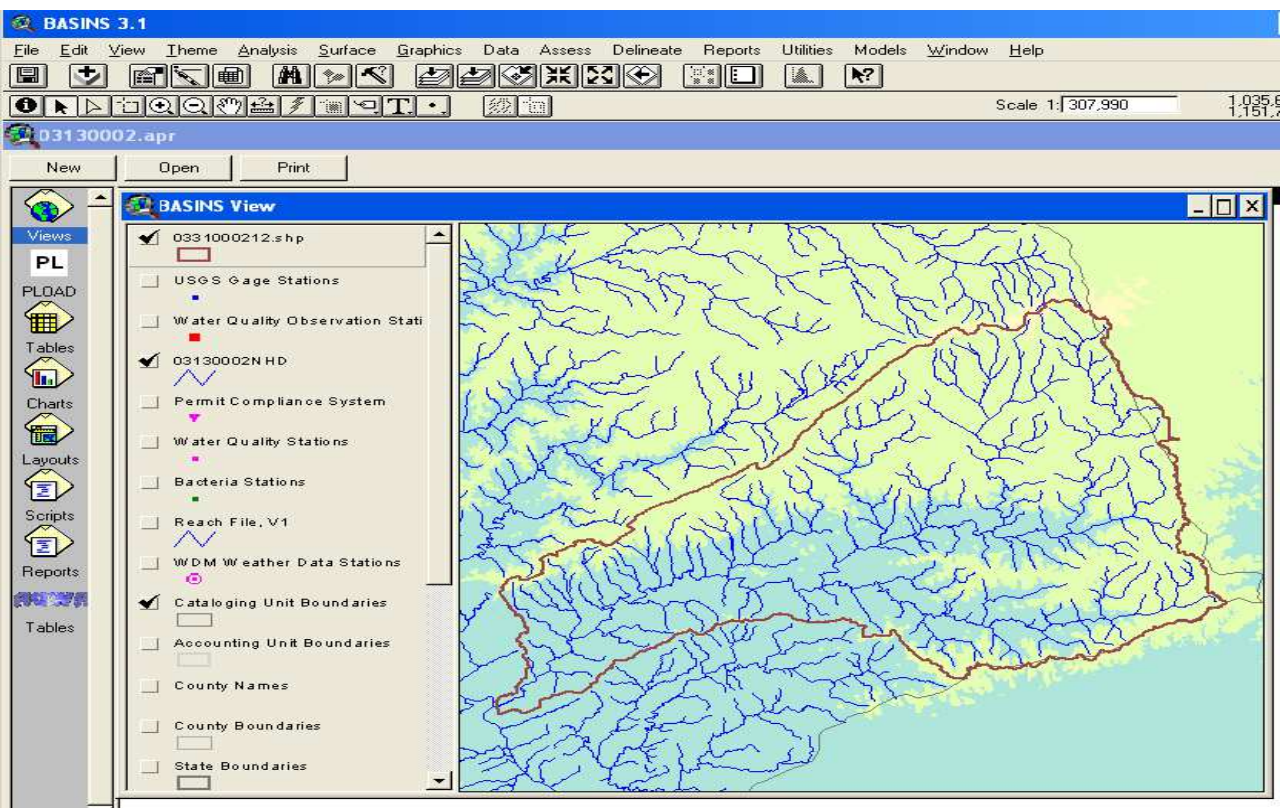

Fig. 3. Overlaying elevation grids, watershed boundary and NHD networks

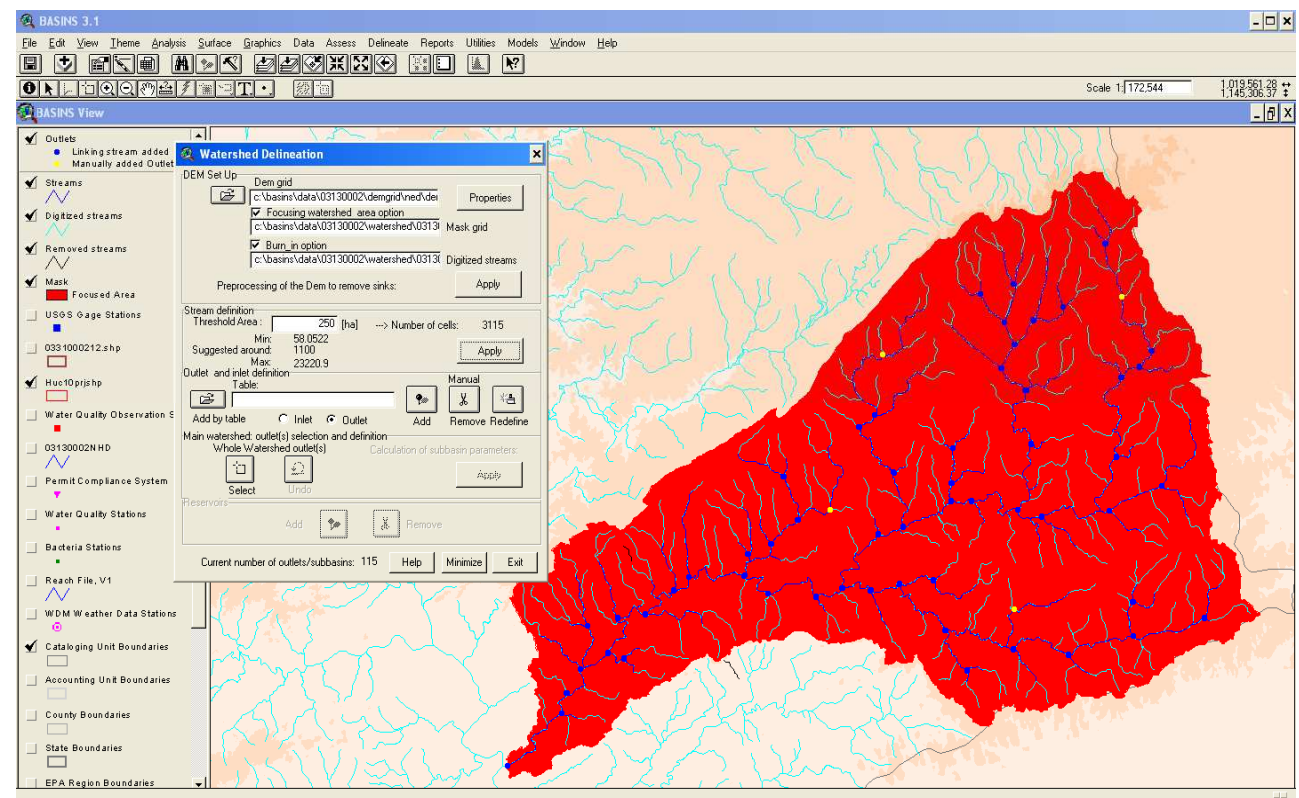

Fig. 4. Digitization of stream networks and nodes 


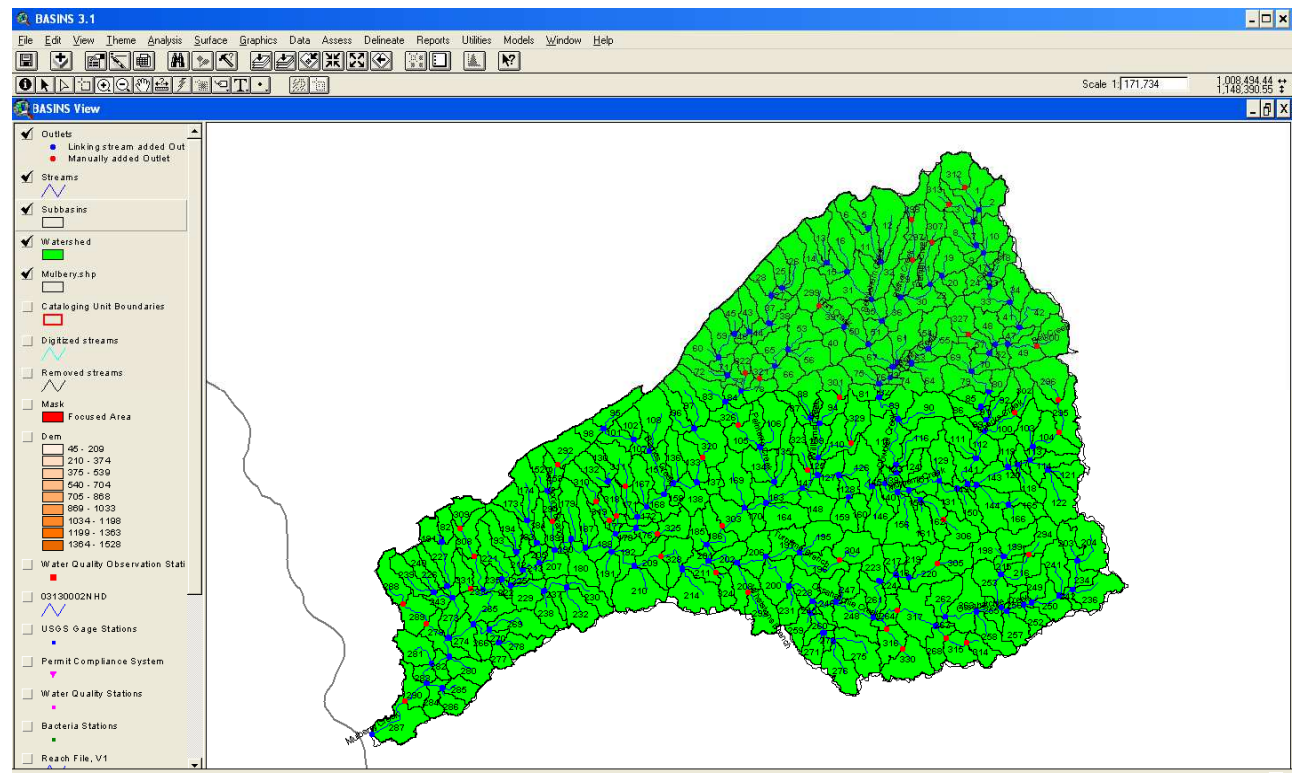

Fig. 5. Creation of sub-basins

Land use grids were loaded in the program and reclassified to standard SWAT codes using the user defined land use look up code created outside of the program. A land use look up code table was prepared to match the land use class to the standard SWAT classification (Table 1).

The state soil layer was also loaded and reclassified using the standard STATSGO soils look up codes. Once the reclassification was complete, soils and land use layers were spatially overlaid to facilitate the creation of hydrological response units (HRUs, Figure 6). An HRU is a result of interaction of land use and soils thus creating a unique land area within each sub-basin. Later, several components of the SWAT results, for example, crop yields, biomass would be based at the HRU level. Multiple HRUs were created by setting $5 \%$ threshold on land use and $10 \%$ threshold on soils.

Upon the successful creation of HRUs the SWAT module was loaded by the system. It started by adding the SWAT database into the model that included the weather and management information. The weather station databases, which included daily precipitation record and daily minimum-maximum temperature records, were created for 10 nearby weather stations outside of the program extracted from the NCDC climate database. During the model simulation, the program assigns the recorded values from the nearest weather station. When data is unavailable for any period of time, the program uses the simulated values based on the information stored for more than 1041 weather stations nationwide (De Luzio et. al., 2000). The other inputs fed into the program were solar radiation, wind speed and relative humidity data. Since none of the weather stations contained these information, it was left to the program to simulate those values from within the internal database. Once the weather station databases were loaded into the system, all necessary SWAT inputs were written using the elevation, land use, soil and weather station databases. This process built the database files containing the information needed to generate default inputs for SWAT. Land management practices, including average nutrients and chemical uses for each 


\begin{tabular}{|c|c|c|c|c|c|}
\hline \multicolumn{3}{|r|}{ NLCD 1992} & \multicolumn{3}{|r|}{ NLCD 2001} \\
\hline GRID & Code & NLCD Description & GRID & Code & NLCD Description \\
\hline 11 & WATR & Open Water & 11 & WATR & Open Water \\
\hline 12 & WATR & Perennial Snow/Ice & 12 & WATR & Perennial Snow/Ice \\
\hline 21 & URML & Low Intensity Residential & 21 & URML & Developed, Open Space \\
\hline 22 & URHD & High Intensity Residential & 22 & URML & Developed, Low Intensity \\
\hline 23 & UIDU & Commercial/Transportation & 23 & URMD & Developed, Medium Intensity \\
\hline 31 & UIDU & Rocks/Sand/Clay & 24 & URHD & Developed, High Intensity \\
\hline 32 & UIDU & Quarries/Strip mines/Pits & 31 & UIDU & Barren Land (Rock/Sand/Clay) \\
\hline 33 & FRST & Clear Cut/Sparse Vegetation & 32 & UIDU & Quarries/Strip Mines/Pits \\
\hline 41 & FRSD & Deciduous Forest & 41 & FRSD & Deciduous Forest \\
\hline 42 & FRSE & Evergreen Forest & 42 & FRSE & Evergreen Forest \\
\hline 43 & FRST & Mixed Forest & 43 & FRST & Mixed Forest \\
\hline 51 & RNGB & Shrublands/Brushes & 52 & RNGB & Shrub/Scrub \\
\hline 81 & HAY & Pasture And Hay & 71 & RNGE & Grasslands/Herbaceous \\
\hline 82 & AGRR & Row Crops & 81 & HAY & Pasture And Hay \\
\hline 83 & AGRC & Small Grains & 82 & AGRR & Cultivated Crops \\
\hline 84 & AGRL & Fallow & 90 & WETF & Forested Wetlands \\
\hline 85 & URML & Recreational Grasses & 95 & WETN & Herbaceous Wetlands \\
\hline 91 & WETF & Woody Wetlands & & & \\
\hline 92 & WETN & Herbaceous Wetlands & & & \\
\hline
\end{tabular}

Table 1. Reclassification of land use grids to standard SWAT codes

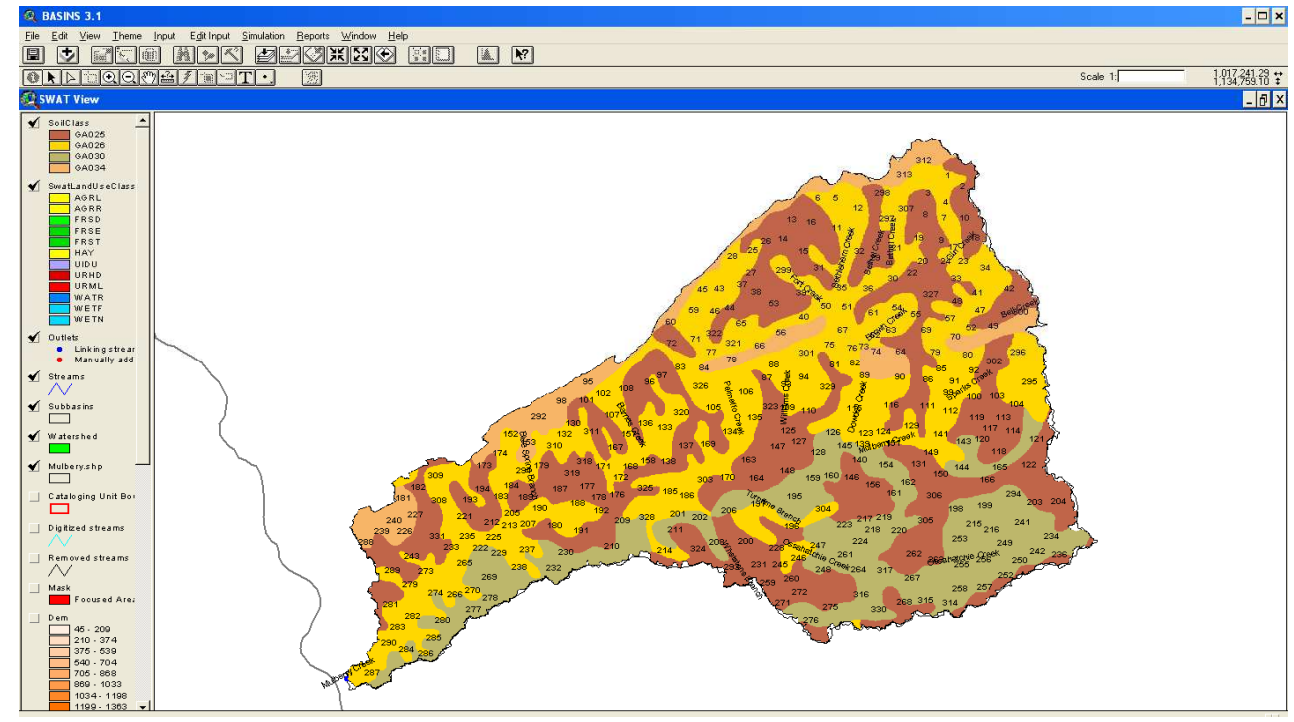

Fig. 6. Land use and soil reclassification and spatial overlay 
type of land use were set to common practices reported in various published extension service papers. Sedimentation and nutrient deposition were evaluated for different land use scenarios using NLCD-1992 and NLCD-2001. Since the data on wind, solar radiation and humidity were not available, built-in data from the SWAT model were used. Curve number and Preistley-Taylor methods were used for modeling the rainfall and evapotranspiration respectively.

\section{Results}

The watershed was divided into 331 sub-basins. The mean elevation of all sub-basins was 216 meters above sea level ranging from 128 to 368 meters. The mean and median sizes of sub-basins were 176.2 hectares and 174.4 hectares respectively. This sub-basins area ranged from 14.3 hectares to 438.9 hectares.

HRUs are determined by the combination of land use and topographic parameters. Therefore, the number of HRUs was different when two land use maps were used. A total of 2089 HRUs were identified by overlaying soils and land use map for land use condition in 1992. On average each sub-basin contained 6.3 HRUs with mean area of each HRU as 27.9 hectares. When NLCD-2001 land use map was overlaid on the same sub-basins with same threshold level, a total of 2158 HRUs were identified. On average each sub-basin contained 6.52 HRUs with the mean area of 27.0 hectares.

Table 2 contains the results from the SWAT run with two sets of land cover data NLCD-1992 and NLCD-2001. Simulations were run for 30 years from 1975 to 2004. SWAT results for the initial years are generally taken as warm up results. Results from the first 10 years were used for calibration and the later twenty years of results (1985-2004) were used for comparative analysis.

\begin{tabular}{|c|c|c|c|c|c|c|}
\hline \multirow{2}{*}{ Variable } & \multicolumn{2}{|c|}{ NLCD-1992 } & \multicolumn{2}{c|}{ NLCD-2001 } & \multirow{2}{*}{ Change } & \multirow{2}{*}{ p-value^ } \\
\cline { 2 - 7 } & Mean & Std. Dev. & Mean & Std. Dev. & & \\
\hline Precipitation (mm) & 1204.29 & 194.46 & 1204.29 & 194.46 & $\mathrm{n} / \mathrm{a}$ & $\mathrm{n} / \mathrm{a}$ \\
Water Yield (mm)* & 218.58 & 75.57 & 224.82 & 75.12 & $2.85 \%$ & 0.001 \\
Sediment Yield (t/ha) & 13.56 & 7.89 & 15.60 & 8.46 & $15.04 \%$ & 0.000 \\
Organic Nitrogen (kg/ha) & 1.89 & 1.03 & 1.98 & 1.00 & $4.76 \%$ & 0.021 \\
Organic Phosphorus (kg/ha) & 0.22 & 0.12 & 0.23 & 0.12 & $4.55 \%$ & 0.027 \\
\hline
\end{tabular}

$\wedge p$-value are for Pair-wise t-test for the comparison of means

* Water Yield = Surface Flow + Lateral Flow + Ground Water Flow-Transportation Loss

Table 2. Average Annual Basin Values (1985-2004)

The modeled area received $1204.29 \mathrm{~mm}$ of precipitation per year. When the land use distribution changed from that of 1992 to 2001, there was $2.85 \%$ increase on water yield $(p=0.001)$ that washed away $15.04 \%$ more sediment $(p<0.001)$. The sediment level increased from $13.56 \mathrm{t}$ / ha to $15.60 \mathrm{t} / \mathrm{ha}$, equivalent of additional 119,096 tons of sedimentation per year from the entire watershed area. Similarly organic nitrogen runoff increased by $4.76 \%$ $(\mathrm{p}=0.021)$ and organic phosphorus increased by $4.55 \%(\mathrm{p}=0.027)$. The $\mathrm{p}$-values are based on 
pairwise t-test for the comparison of means and are significant at $5 \%$ level of significance. Graphical comparison of sediment loadings and organic nitrogen and phosphorus runoff under two land use scenarios are given in figures $7-9$.

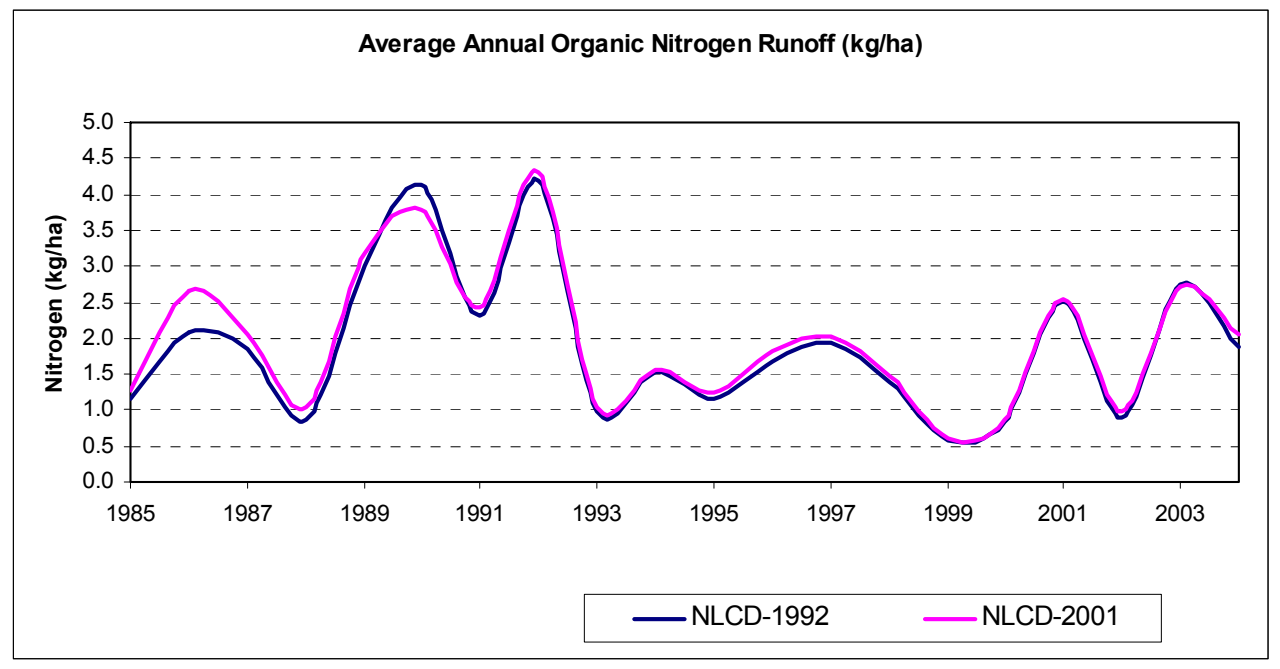

Fig. 7. Simulated average organic nitrogen runoff (1985-2004)

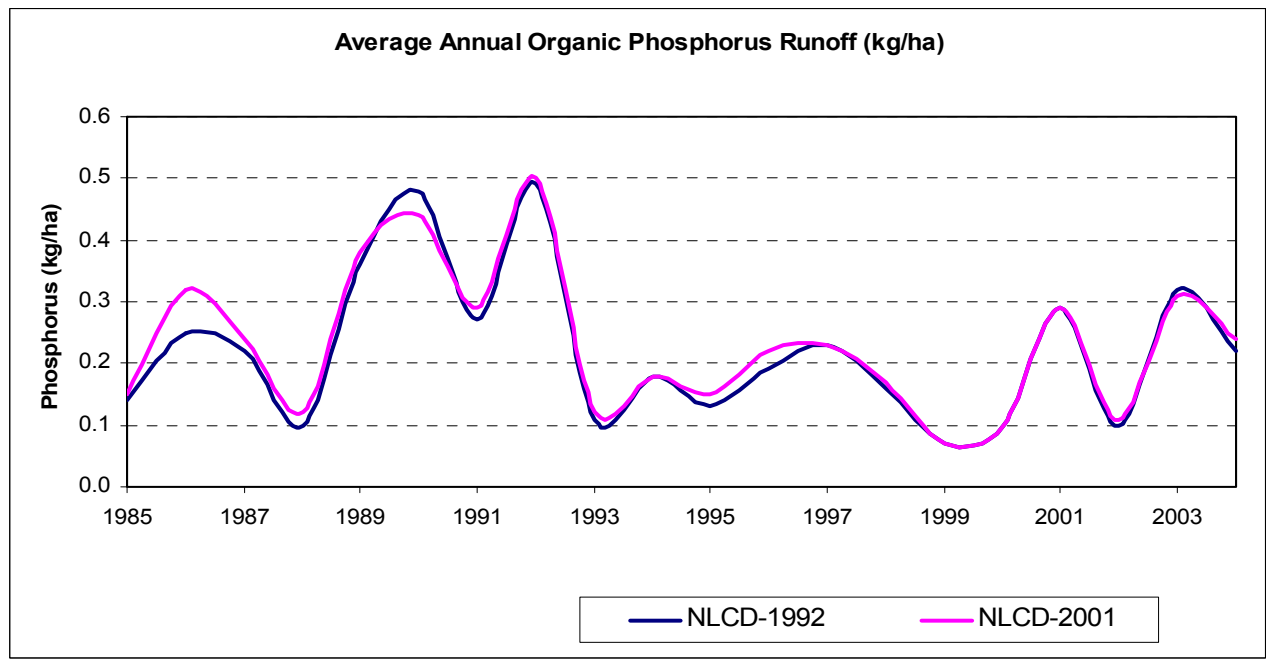

Fig. 8. Simulated average organic phosphorus runoff (1985-2004) 


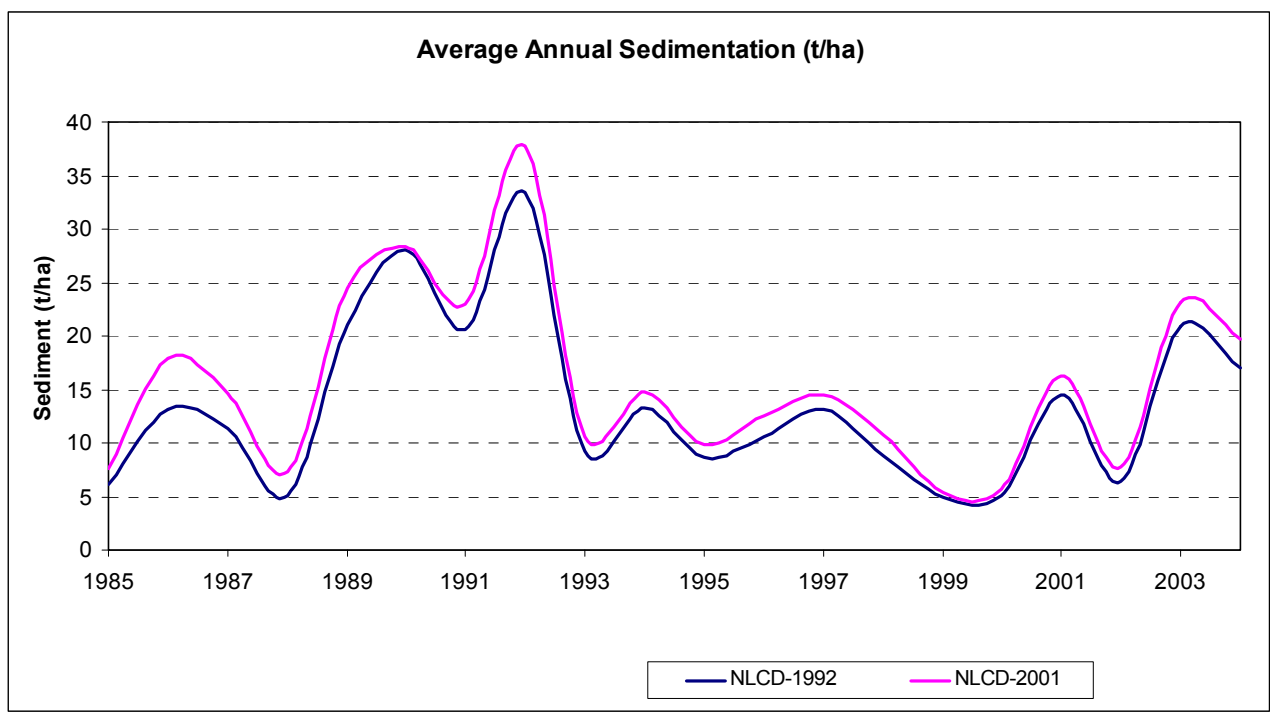

Fig. 9. Simulated average sediment runoff (1985-2004)

\section{Discussion}

This study demonstrates how changes in land cover scenarios can affect the water quality in the catchment area with quantitative findings. These results are basic to the understanding of water quality impacts of land use change which ultimately helps regional planners and watershed management policy makers by providing the estimates of changes in water quality when land use changes in an area over long run. King and Balogh (2001) applied the methodology to simulate water quality impacts associated with converting farmland and forests to turfgrass. They found SWAT to be a useful tool in evaluating risk assessments associated with land use conversions.

The application of the model can be extended to include much detailed land use and soil distribution facilitating the short-run assessment of point and non-point source pollution. Using recent satellite images to create maps with details of cropping patterns will help to understand the impact of alternative best management practices such as minimum or notillage practices and reduced use of fertilizers and pesticides (e.g. Santhi et al., 2001). The fact that the watershed level results can be disaggregated to the individual hydrological response units helps to achieve precise estimate of water quality impact at much smaller level. While these biophysical models are extremely valuable in assessing the physical impacts of BMPs on quantity and quality of water bodies, the results can be combined into a more complex bioeconomic modeling to estimate the impacts of land use changes with respect to economic profitability and the water quality. Bhattarai et al. (2008) demonstrated that a reduction in cropland improved the water quality with an overall loss in agricultural returns. Results from these biophysical results combined with economic analysis helps in setting up a policy that maintains the balance between the water quality and economic incentives among the stakeholders. 


\section{Limitations of the study}

The land in the study area is predominantly forested. The shares of other land uses such as developed land, agricultural land, and wetland, are relatively small. During the HRU distribution process, the model picks up the dominant land use as determined by the threshold level. Thus unique land uses with very small areas may be ignored, leaving out the effects of specific land use in a localized area. The selected sub-watershed does not have enough water quality observation sites and USGS gage stations to calibrate and validate simulated results with the real-time observed daily streamflow data and water quality data. The objective of the study was to compare the levels of nitrogen, phosphorus and sediment achieved under alternative land use scenarios at the aggregated level, ceteris paribus, the results are still valid for comparative analysis.

\section{Conclusion}

Change in land use distribution had a significant impact on the levels of organic nitrogen and phosphorus runoff and sediment loadings coming out of the watershed. The forest land decreased by $16.6 \%$ and mostly the developmental use and agricultural cultivation took that share resulting in overall average annual nutrient runoff increase by $4.76 \%$ for nitrogen and $4.55 \%$ for phosphorus. Average annual sediment loadings at the basin level increased by more than $15.04 \%$. With the same amount of rainfall and climate conditions, water flowing to the main channel from the catchment area was $2.85 \%$ higher. This result confirms to hypothesis that with less vegetative cover, more impervious surfaces in urban areas and increasing fragile agricultural land, there would be less percolation and higher runoff. This resulted in higher organic nitrogen and phosphorus concentration in the discharged water. This study also indicates SWAT's relative strength in quantifying the effect of changes in land use distribution and land management scenarios on water quality.

\section{Acknowledgement}

Partial funding for this research was provided by the Center for Forest Sustainability through the Peaks of Excellence program at Auburn University. Additional funds were also provided by Auburn University's Environmental Institute. The views expressed in this article are of authors and do not necessarily represent the views of the funding institution or the institution the authors represent.

\section{References}

Bhattarai, G., P. Srivastava, L. Marzen, D. Hite, and U. Hatch. 2008. Assessment of Economic and Water Quality Impacts of Land Use Change Using a Simple Bioeconomic Model. Environmental Management 42(1): 122-131.

Bhuyan, S.J., L.J. Marzen, J.K. Koelliker, J.A. Harrington Jr., and P.L. Barnes. 2001. "Assessment of Runoff and Sediment Yield Using Remote Sensing, GIS and AGNPS." Journal of Soil and Water Conservation 57(5):351-364.

Borah, D.K., and M. Bera. 2003. SWAT Model Background and Application Reviews. Paper presented at American Society for Engineering in Agricultural, Food, and 
Biological Systems Annual International Meeting, Las Vegas, Nevada, USA. July 27-July 30, 2003.

DiLuzio, M., R. Srinivasan, J.G. Arnold, and S.L. Neitsch. 2002. ArcView Interface for SWAT2000: User's Guide. TWRI Report TR-193, Texas Water Resources Institute, Texas. 2002.

Intarapapong, W., D. Hite, and L. Reinschmiedt. 2002. "Water Quality Impacts of Conservation Agricultural Practices in the Mississippi Delta." Journal of the American Water Resources Association, 38(2):507-515, April 2002.

King, K. W. and J. C. Balogh. 2001. Water Quality Impacts Associated with Converting Farmland and Forests to Turfgrass. Transactions of the ASAE 44(3): 569-576.

Liao, H., and U.S. Tim. 1997. “An Interactive Modeling Environment for Non-point Source Pollution Control." Journal of the American Water Resources Association 33(3):1-13.

Maidment, D. R. (eds.). 2002. Arc Hydro: GIS for Water Resources. ESRI Press, Redlands, California (pp. 73).

Mankin, K. R., J. K. Koelliker, and P. K. Kalita. 1999. “Watershed and Lake Water Quality Assessment: An Integrated Modeling Approach." Journal of the American Water Resources Association 35(5):1069-1080.

Marzen, L.J., S.J.Bhuyan, J.A. Harrington, J.K. Koelliker, L.D. Frees, and C.G. Volkman. 2000. "Water Quality Modeling in the Red Rock Creek Watershed, Kansas." Proceedings of the Applied Geography Conference 23: 175-182.

Neitsch, S.L., J.G. Arnold, J.R. Kiniry, J.R. Williams, and K.W. King. 2002. Soil and Water Assessment Tool: Theoretical Documentation, Version 2000. Texas Water Resources Institute, College Station, Texas, TWRI Report TR-191.

Neitsch, S.L., J.G. Arnold, J.R. Kiniry, R. Srinivasan, and J.R. Williams. 2002. Soil and Water Assessment Tool: User's Guide, Version 2000. Texas Water Resources Institute, College Station, Texas, TWRI Report TR-192.

Saleh, A., J.G. Arnold, P.W. Gassman, L.W. Hauck, W.D. Rosenthal, R.R. Williams, and A.M.S. McFarland. 2000. Application of SWAT for the upper north Bosque Watershed. Transactions of the ASAE 43(5):1077-1087.

Santhi, C., J. G. Arnold, J. R. Williams, L. M. Hauck, and W. A. Dugas. 2001. Applications of a Watershed Model to Evaluated Management Effects on Point and Nonpoint Source Pollution. Transactions of the ASAE 44(6): 1559-1570.

U.S. Department of Agriculture Natural Resources Conservation Service (USDA-NRCS). 2002. Major Land Resource Area Regional \#15. Auburn, AL. Available online at http://www.mo15.nrcs.usda.gov/alsoilnt/almlramp.html.

United States Census Bureau, 1990. States and County Quick Facts. Online at: http://quickfacts.census.gov/qfd/index.html

United States Census Bureau, 2000. States and County Quick Facts. Online at: http://quickfacts.census.gov/qfd/index.html

United States Environment Protection Agency (USEPA). Total Maximum Daily Loads Factsheet. Available online at http://www.epa.gov/owow/tmdl/ (accessed 11/18/2003)

United States Environmental Protection Agency (USEPA). 1998. "National Water Quality Inventory: 1996 Report to Congress." Washington, DC. 
United States Environmental Protection Agency (USEPA). 1999. United Watershed Assessment Factsheet. Available online at http://www.epa.gov/owow/uwa.

United States Environmental Protection Agency (USEPA). 2001. Better Assessment Science Integrating Point and Nonpoint Sources. BASINS Users' manual, Version 3.0.

United States Environmental Protection Agency (USEPA). Surf Your Watershed. Online at: http:/ / www.epa.gov/surf/

United States Geologic Survey (USGS). 2003. National Land Cover Characterization 2001. Available online at http://landcover.usgs.gov/natlandcover_2000.asp.

USGS Seamless Data Distribution system, National Center for Earth Resources Observation and Science (EROS). Online at:

http://seamless.usgs.gov/website/seamless/index.asp 


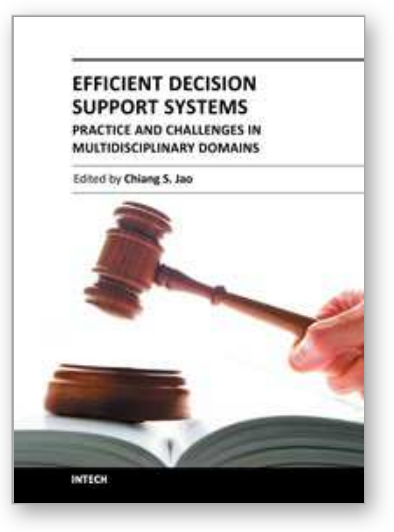

\author{
Efficient Decision Support Systems - Practice and Challenges in \\ Multidisciplinary Domains \\ Edited by Prof. Chiang Jao
}

ISBN 978-953-307-441-2

Hard cover, 478 pages

Publisher InTech

Published online 06, September, 2011

Published in print edition September, 2011

This series is directed to diverse managerial professionals who are leading the transformation of individual domains by using expert information and domain knowledge to drive decision support systems (DSSs). The series offers a broad range of subjects addressed in specific areas such as health care, business management, banking, agriculture, environmental improvement, natural resource and spatial management, aviation administration, and hybrid applications of information technology aimed to interdisciplinary issues. This book series is composed of three volumes: Volume 1 consists of general concepts and methodology of DSSs; Volume 2 consists of applications of DSSs in the biomedical domain; Volume 3 consists of hybrid applications of DSSs in multidisciplinary domains. The book is shaped decision support strategies in the new infrastructure that assists the readers in full use of the creative technology to manipulate input data and to transform information into useful decisions for decision makers.

\title{
How to reference
}

In order to correctly reference this scholarly work, feel free to copy and paste the following:

Gandhi Bhattarai, Diane Hite and Upton Hatch (2011). Estimating the Impact on Water Quality under Alternate Land Use Scenarios: A Watershed Level BASINS-SWAT Modeling in West Georgia, United States, Efficient Decision Support Systems - Practice and Challenges in Multidisciplinary Domains, Prof. Chiang Jao (Ed.), ISBN: 978-953-307-441-2, InTech, Available from: http://www.intechopen.com/books/efficient-decisionsupport-systems-practice-and-challenges-in-multidisciplinary-domains/estimating-the-impact-on-water-qualityunder-alternate-land-use-scenarios-a-watershed-level-basins-s

\section{INTECH}

open science | open minds

\section{InTech Europe}

University Campus STeP Ri

Slavka Krautzeka 83/A

51000 Rijeka, Croatia

Phone: +385 (51) 770447

Fax: +385 (51) 686166

www.intechopen.com

\section{InTech China}

Unit 405, Office Block, Hotel Equatorial Shanghai

No.65, Yan An Road (West), Shanghai, 200040, China 中国上海市延安西路65号上海国际贵都大饭店办公楼 405 单元

Phone: +86-21-62489820

Fax: +86-21-62489821 
(C) 2011 The Author(s). Licensee IntechOpen. This chapter is distributed under the terms of the Creative Commons Attribution-NonCommercialShareAlike-3.0 License, which permits use, distribution and reproduction for non-commercial purposes, provided the original is properly cited and derivative works building on this content are distributed under the same license. 